\title{
Mantle flow below the central and greater Alpine region: insights from SKS anisotropy analysis at AlpArray and permanent stations
}

\author{
Laura Petrescu $^{1,2}$, Silvia Pondrelli ${ }^{1}$, Simone Salimbeni ${ }^{1}$, Manuele Faccenda ${ }^{3}$, and the AlpArray Working Group ${ }^{+}$ \\ ${ }^{1}$ Istituto Nazionale di Geofisica e Vulcanologia, Bologna, Italy \\ ${ }^{2}$ National Institute for Earth Physics, Bucharest, Romania \\ ${ }^{3}$ Department of Geoscience, University of Padua, Padua, Italy

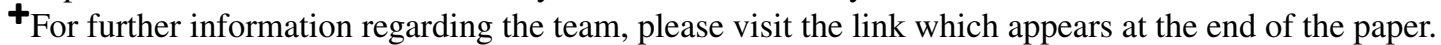

Correspondence: Silvia Pondrelli (silvia.pondrelli@ingv.it)

Received: 21 January 2020 - Discussion started: 19 February 2020

Revised: 21 May 2020 - Accepted: 10 June 2020 - Published: 8 July 2020

\begin{abstract}
The Alpine chain in western and central Europe is a complex orogen developed as a result of the AfricanAdriatic plate convergence towards the European continent and the closure of several Tethys oceanic branches. Seismic tomography studies detected high-wave-speed slabs plunging beneath the orogen to variable depths and a potential change in subduction polarity beneath the Central Alps. Alpine subduction is expected to leave a significant imprint on the surrounding mantle fabrics, although deformation associated with the Hercynian Orogeny, which affected Europe prior to the collision with Adria, may have also been preserved in the European lithosphere. Here we estimate SKS anisotropy beneath the central and greater Alpine region at 113 broadband seismic stations from the AlpArray experiment as well as permanent networks from Italy, Switzerland, Austria, Germany, and France. We compare the new improved dataset with previous studies of anisotropy, mantle tomography, lithospheric thickness, and absolute plate motion, and we carry out Fresnel analysis to place constraints on the depth and origin of anisotropy. Most SKS directions parallel the orogen strike and the orientation of the Alpine slabs, rotating clockwise from west to east along the chain, from -45 to $90^{\circ}$ over a $\sim 700 \mathrm{~km}$ distance. No significant changes are recorded in Central Alps at the location of the putative switch in subduction polarity, although a change in direction variability suggests simple asthenospheric flow or coupled deformation in the Swiss Central Alps transitions into more complex structures beneath the Eastern Alps. SKS fast axes follow the trend of high seismic anomalies across the Alpine Front, far from the present-day boundary, suggesting slabs
\end{abstract}

act as flow barriers to the ambient mantle surrounding them for hundreds of $\mathrm{km}$. Further north across the foreland, SKS fast axes parallel Hercynian geological structures and are orthogonal to the Rhine Graben and crustal extension. However, large splitting delay times $(>1.4 \mathrm{~s}$ ) are incompatible with a purely lithospheric contribution but rather represent asthenospheric flow not related to past deformational events. West of the Rhine Graben, in northeastern France, anisotropy directions are spatially variable in the proximity of a strong positive seismic anomaly in the upper mantle, perhaps perturbing the flow field guided by the nearby Alpine slabs.

\section{Introduction}

The Alpine tectonic region is a complex orogenic system formed as a result of the interaction between Africa and Europe throughout the Cenozoic era. The northward convergence of Adria led to the closure of several Tethys oceanic branches generating the arcuate Alpine-DinaridesCarpathian orogenic system and the circum-Alpine rifts in central and western Europe (Fig. 1; Schmid et al., 2004; Handy et al., 2010). While several geologic and geophysical studies suggest that Adria is the upper plate beneath the Western Alps and Central Alps (the latter considered here to include Switzerland, westernmost Austria, and northern Italy), the origin of the eastern Alpine slab is the subject of ongoing debate. Several tomography studies show seismically fast subducted bodies down to $250-300 \mathrm{~km}$ beneath the Alps (e.g. Lippitsch et al., 2003; Piromallo and Morelli, 
2003; Giacomuzzi et al., 2011; Zhu et al., 2015; Zhao et al., 2016), but their geometry, extent, and orientation remain controversial (e.g. Lippitsch et al., 2003; Mitterbauer et al., 2011; Piromallo and Faccenna, 2004), with some studies further suggesting that the subduction direction changes polarity beneath the Central Alps to Eastern Alps (e.g. Lippitsch et al., 2003; Schmid et al., 2004; Handy et al., 2015).

The collision between Adria and Europe is thought to have caused orogen-parallel asthenospheric flow (Barruol et al., 2011; Bokelmann et al., 2013; Salimbeni et al., 2018) and extrusion of the Eastern Alps towards the Pannonian Basin (Kummerow et al., 2006; Bokelmann et al., 2013). In the Eastern Alps, Qorbani et al. (2015) also suggested that mantle flows above a deeper detached slab. Anisotropy studies in the Mediterranean suggested toroidal flow is likely induced by subducting and/or retreating slabs (e.g. Civello and Margheriti, 2004; Lucente et al., 2006; Baccheschi et al., 2007; Salimbeni et al., 2008; Buontempo et al., 2008; Diaz et al., 2010) and that trench-normal directions in the back-arc side may reorient to trench-parallel directions on the other side of the slab (Margheriti et al., 2003). While stations located in the high-topography Western Alps are likely in correspondence of a forearc setting (Barruol et al., 2011), the uncertain origin and extent of the slab in the Eastern Alps (Lippitsch et al., 2003; Piromallo and Faccenna, 2004; Mitterbauer et al., 2011; Zhao et al., 2016) may place the stations in a hinterland setting, changing the way mantle flow can be interpreted with respect to the plunging Alpine slab. North of the Alpine Front, the European lithosphere, which has been shaped by pre-Alpine Hercynian orogeny, experienced lithospheric thermal thinning due to Cenozoic rifting and possible mantle plume activity (e.g. Goes et al., 1999; Dèzes et al., 2004). It is thus uncertain how far north and northwest collision-related asthenospheric flow may be extrapolated below the European foreland. Significant debate exists concerning the nature of the observed seismic anisotropy, with interpretations such as frozen-in pre-Hercynian palaeosubduction systems (Babuska and Plomerová, 2001), lithospheric deformation imprinted by the opening of the Rhine Graben (Walther et al., 2013), and a combination of basal drag due to plate motion and lithosphere-asthenosphere boundary topography influencing the mantle flow beneath (Bormann et al., 1996).

With the advent of the AlpArray project (Hetényi et al., 2018), seismic station density significantly increased in Europe, providing an unparalleled wealth of seismic data and an excellent opportunity to probe the continental interior in the greater Alpine tectonic area. To help determine the past and present plate deformation and place constraints on the geodynamic controversies concerning slab geometries and the extent of collision-related asthenospheric flow, we determine upper-mantle seismic anisotropy using SKS splitting analysis at both permanent and AlpArray seismic stations located across the Po Basin, the Central Alps and Eastern Alps, the Rhine Graben, and the Molasse Basin (Fig. 2). SKS are core-refracted shear waves radiated by distant earthquakes that split in the presence of anisotropy, generally associated with strain-induced mineral alignment in the lithosphere and asthenosphere (Savage, 1999; Fouch and Rondenay, 2006; Long and Becker, 2010). SKS analysis thus yields direct observations of azimuthal anisotropy in the upper mantle, offering the possibility to passively probe the deformation of continents and mantle geodynamics (Silver, 1996). The broad and uniform coverage of the new AlpArray network allows for mapping the anisotropy with unprecedented density, providing fundamental insights into the distribution of deformation in the upper mantle.

\section{Tectonic and geodynamic setting}

The geological history of the Alps and the Mediterranean includes the sequential opening and closure of multiple Tethys and neo-Tethys oceanic branches throughout the Mesozoic, whose remnants were obducted on the southern margin of Europe (Fig. 1). After the collision between Adria and Europe started $35 \mathrm{Ma}$ ago, the Adria indenter fuelled by the continued northward push of Africa rotated anticlockwise with respect to Europe, thrusting over Europe (Coward and Dietrich, 1989; Froitzheim et al., 2008; Handy et al., 2010). Slab break-off was initiated, although time estimates vary between studies: 35-25 Ma (e.g. Piromallo and Faccenna, 2004) to 32-30 Ma (Sinclair, 1997) and may have migrated laterally beneath the Eastern Alps and further into the Carpathians before $20 \mathrm{Ma}$ (Ustaszewski et al., 2008).

Geographically, the Alps comprise the Eastern Alps, lithologically linked to the Adria passive continental margin, and the Western Alps, comprising European terrains and ophiolite-bearing nappes. The Southern Alps, the northern continental margin of Adria unaffected by Alpine metamorphism, are separated from the Central Alps and Eastern Alps by the E-W-oriented Insubric Fault, marking the suture between Adria and Europe and the Periadriatic Fault (Fig. 1), which accommodated shortening between Adria and Europe and post-collisional orogen-parallel extension (e.g. Schmid et al., 1989; Rosenberg et al., 2015). In this paper, we refer to the Central Alps as the approximate region comprising the limit between the Western Alps and Eastern Alps in Switzerland, west Austria, and northern Italy (Fig. 1). Two major synorogenic basins flank the north and south of the Alpine orogen: the northern Molasse Basin, a typical foreland sedimentary basin, and the Po Basin to the south, also a foreland basin for the Apennines (Allen et al., 1986). To the north of the Alpine chain, the European foreland comprises terranes assembled during the pre-Alpine Hercynian Orogeny (280-380 Ma) along the E-W-trending Saxothuringian-Moldanubian suture zone (Fig. 1). The interaction between Africa and Eurasia caused the development of a synorogenic intracontinental foreland rift system which cross-cuts Hercynian palaeoboundaries (Ziegler, 1992). This 
(a)
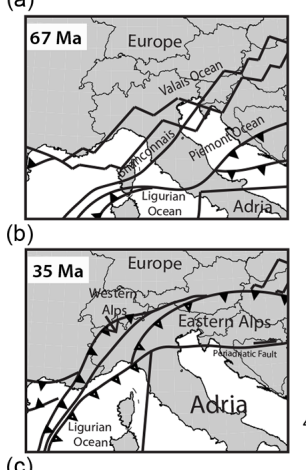

(c)

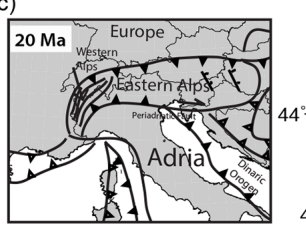

(d)

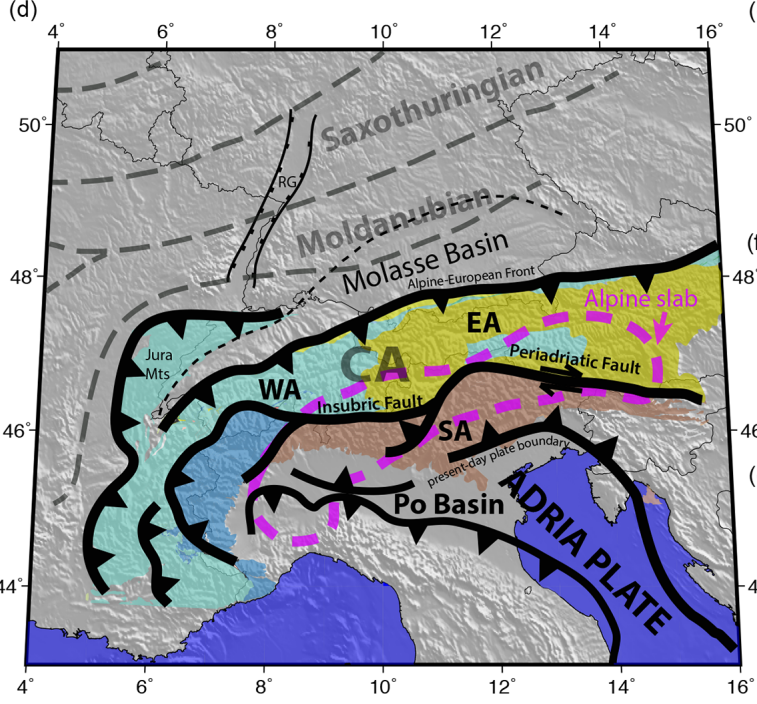

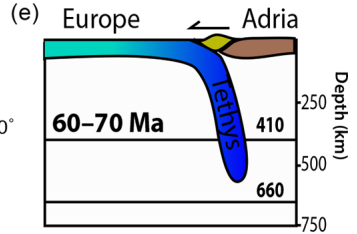

(f)

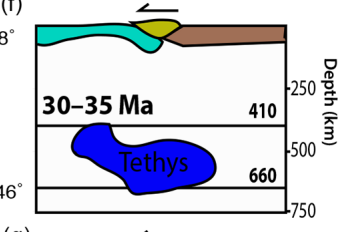

(g)

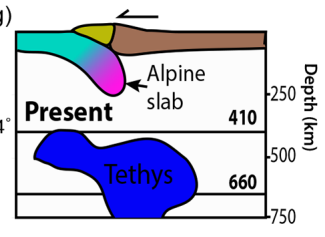

Figure 1. Geographical units of the Alpine chain and surrounding regions. Coloured areas representing the main geological regions are based on Schmid et al. (2008) and mark the Eastern Alps (EA, yellow), the Southern Alps (SA, brown), and the Western Alps (WA, light and dark blue). TW: Tauern window. Dashed pink line marks the probable outline of the Alpine slab, after Mitterbauer et al. (2011). (a-c) Plate tectonic reconstruction snapshots of the region for the past $67 \mathrm{Ma}$, according to Handy et al. (2010). (e-g) Time-lapse images of probable trench migration and slab break-off beneath the Alps for the past $70 \mathrm{Ma}$, after Piromallo and Faccenna (2004). The section showing the Alpine slab (pink), attached to the European lithosphere (cyan), may only be applicable to the Western Alps and Central Alps. In the Eastern Alps, the slab may be attached to Adria (yellow and brown).

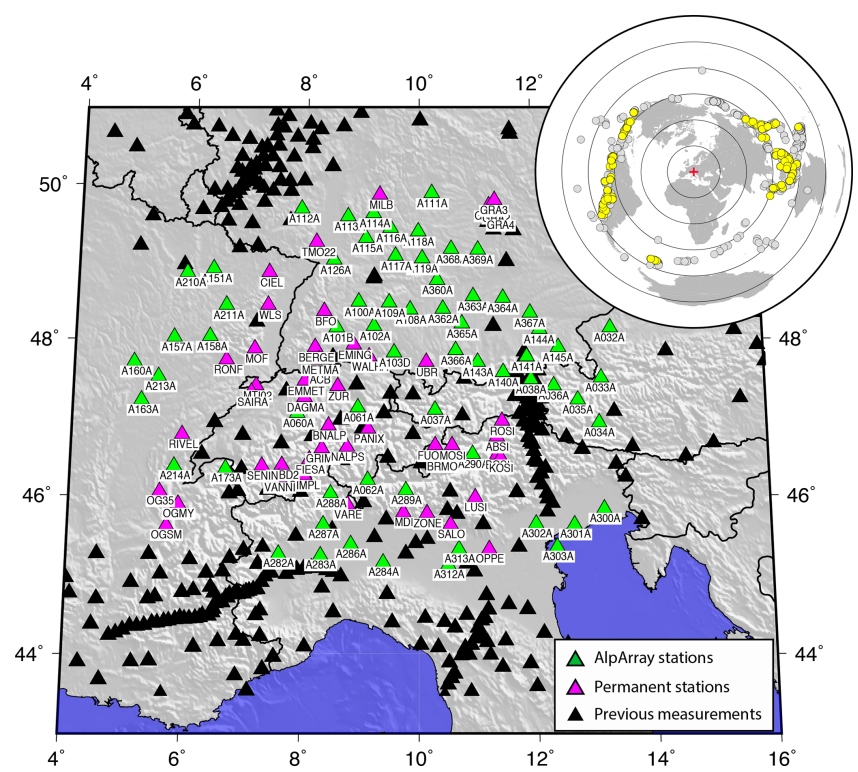

Figure 2. Topographic and political map of the central Alpine region showing broadband seismic stations (triangles) whose data were analysed in this study, including AlpArray temporary stations (green), permanent stations (magenta), and stations with previous SKS measurements (black). Inset shows the location of all earthquakes recorded between 2015-2019 (grey circles), those analysed in this study (yellow circles), and the centre of our study area (red cross). system includes the Rhine Graben, an Eocene-Oligocene passive rift that may have been generated along pre-existing planes of weakness in response to the Alpine and Pyrenean collisional phases (Schumacher, 2002; Dèzes et al., 2004). During the Miocene, the European foreland lithosphere suffered thermal weakening due to the activation of a mantle plume system beneath western and central Europe, coeval with the northeast Atlantic plumes (e.g. Goes et al., 1999; Ritter et al., 2001).

Tomographic images of the upper-mantle structure beneath the Alpine region generally show slow seismic anomalies beneath part of the Western Alps (WA), the Molasse Basin (MB), and the eastern Po Basin. Fast seismic anomalies generally associated with the Alpine slab (Fig. 1) are present beneath the western Po Basin, the Southern Alps (SA), and the Eastern Alps (EA) (e.g. Lippitsch et al., 2003; Piromallo and Morelli, 2003; Giacomuzzi et al., 2011; Zhu et al., 2015; Zhao et al., 2016). The outline and internal properties of these anomalies are variable between studies, casting doubt on their lateral and depth extent, dipping direction, or even whether they are continuous beneath the Alps. Although the general consensus regards the fast anomaly beneath the Western Alps as a south-southeastward subducted oceanic margin of Europe, the eastern segment may dip slightly towards the north and may be attached to Adria (Lippitsch et al., 2003; Handy et al., 2015). Furthermore, while the high seismic wave velocity Alpine "root" is present down to 250$300 \mathrm{~km}$ depth, at least beneath the Western Alps (Piromallo 
and Faccenna, 2004; Zhao et al., 2016), a deeper slab, possibly the remnant Alpine Tethys (Fig. 1), extends down to the bottom of the transition zone beneath the Eastern Alps (Piromallo and Faccenna, 2004; Mitterbauer et al., 2011).

\section{Methods and data}

SKS waves are excellent tools to study the anisotropy of the upper mantle beneath individual stations (e.g. Savage, 1999; Long et al., 2017). They are $S$ waves excited by distant earthquakes that refracted through the Earth's outer core as $\mathrm{P}$ waves and reconverted to $\mathrm{S}$ waves upon entering the mantle. When entering an anisotropic medium, SKS splits into two orthogonally polarized waves that propagate at different speeds. The direction of the fast wave, $\varphi$, is generally parallel to the azimuthal anisotropy axis and the time delay, $\delta t$, can suggest the depth and/or strength of the anisotropy. Since anisotropy is thought to be weak in the lower mantle (Niu and Perez, 2004) and in the transition zone (e.g. Tommasi et al., 2004), SKS waves are generally associated with upper-mantle anisotropy and thought to be induced by the alignment of olivine crystals in the maximum strain direction (Ribe, 1989; Savage, 1999; Mainprice et al., 2000).

When SKS splitting occurs, energy is present on both radial and tangential components of the seismogram, resulting in an elliptical particle motion (Fig. 3). If no energy is present on the tangential, the particle motion is linear and the SKS splitting measurement is declared null (e.g. Wüstefeld and Bokelmann, 2007; Long and Silver, 2009). Several situations can result in a null SKS split: the presence of multiple anisotropic layers whose combined signal destructively interferes (e.g. Barruol and Hoffmann, 1999) or the azimuth of the incoming SKS wave corresponds to the anisotropy orientation or to a direction perpendicular to it. To determine the $\varphi$ and $\delta t$ parameters, we rotated the horizontal seismogram components in the great circle arc reference frame and linearized the particle motion in the window encompassing the SKS arrival (Fig. 3), by minimizing the energy on the tangential component, as implemented in the Sheba software (Wüstefeld et al., 2010). Grid search parameters are 0.025 for $\delta t$ and $1^{\circ}$ for $\varphi$, and error calculations are based on the Silver and Chan (1991) method, under the assumption of Gaussian noise. We allow measurements where the SKS phase is clear, the particle motion is successfully linearized, and the misfit surface minimizes around one $\delta t-\varphi$ solution pair. The majority of allowed individual measurements have $\varphi$ errors less than $20^{\circ}$ ( $81 \%$ of our results, while $19 \%$ are between 20 and $40^{\circ}$ ) and $\delta t$ errors less than $1 \mathrm{~s}$. After misfit stacking, errors decrease significantly, with single-station measurement errors averaging to $2.0^{\circ}$ for $\varphi$ and $0.025 \mathrm{~s}$ for $\delta t$. To avoid spurious results potentially introduced by lower-mantle anomalies (Restivo and Helffrich, 2006), we only kept measurements where the difference between the source polariza- tion of the SKS phase and its back-azimuth was found to be less than $20^{\circ}$.

We used data from 113 permanent and temporary seismic stations, including 65 stations from the temporary AlpArray network (Heteényi et al., 2018), operational since 2015, and 48 stations from multiple permanent networks (Fig. 2): 6 stations from Province Sudtirol Network (SI), 6 Italian National Seismic Network stations (IV), 20 Swiss Seismological Network stations $(\mathrm{CH}), 8$ German Regional Seismic Network stations (GR), and 8 French National Seismic Network stations (FR). We selected 542 earthquakes that occurred between 2015 and 2019, with magnitudes $M_{\mathrm{w}}>5.8$ and epicentral distances in the range of $85-130^{\circ}$, recorded at 113 broadband seismic stations (Fig. 2). Before the manual selection for further analysis, data were filtered with a zerophase Butterworth bandpass filter between 0.04 and $0.3 \mathrm{~Hz}$, a common corner frequency in this kind of analysis. Other SKS studies use a similar filter bandwidth (e.g. Darbyshire et al., 2015; Liddell et al., 2017; Venereau et al., 2019) or an even higher corner frequency, i.e. $0.09-0.35 \mathrm{~Hz}$ (Eakin et al., 2015). In the Alpine region, some authors did not apply any filtering (Bokelman et al., 2013; Qorbani et al., 2015), while others used $0.02-1 \mathrm{~Hz}$ (Wustefeld and Bokelman, 2007), 0.02-0.2 Hz (Barruol et al., 2011; Salimbeni et al., 2018), or a range of bandpass filters between 2-10, 5-20, and 10-50 s depending on the available data.

After initial inspection of raw three-component seismograms and post-analysis splitting quality control, we obtained between 3 and 35 viable solutions per station, including null measurements (see Tables S1 and S2 in the Supplement). Average SKS directions were computed using the standard circular mean of fast-axis back-azimuth angles (Davis, 2002) and average delay time using standard linear mean. However, since this technique may not work well in cases when single-station circular distributions are too scattered, we also carry out misfit surface stacking from individual non-null SKS splitting solutions, weighted by their signal-to-noise ratio (Restivo and Helffrich, 1999). Since high back-azimuthal variations may yield high differences between the two averages (see Table S3), we compare them to assess single-station measurement heterogeneity (Fig. 3).

\section{Results}

In Fig. 4 all measurements are shown (see Tables S1 and S2). Most of the SKS fast axes follow a general NE-SW trend, especially those located in the higher Alpine elevation region (Fig. 4a). In the Western Alps and north of the Alpine Front (within the Molasse Basin) some N-S directions are also recorded. In the Southern Alps and Eastern Alps, anisotropy measurements progressively orient along an $\mathrm{E}-\mathrm{W}$ direction, following a large-scale clockwise rotation of the fast axes along the chain. North of the Alpine Front, the Rhine Graben marks the transition between two different data distributions: 


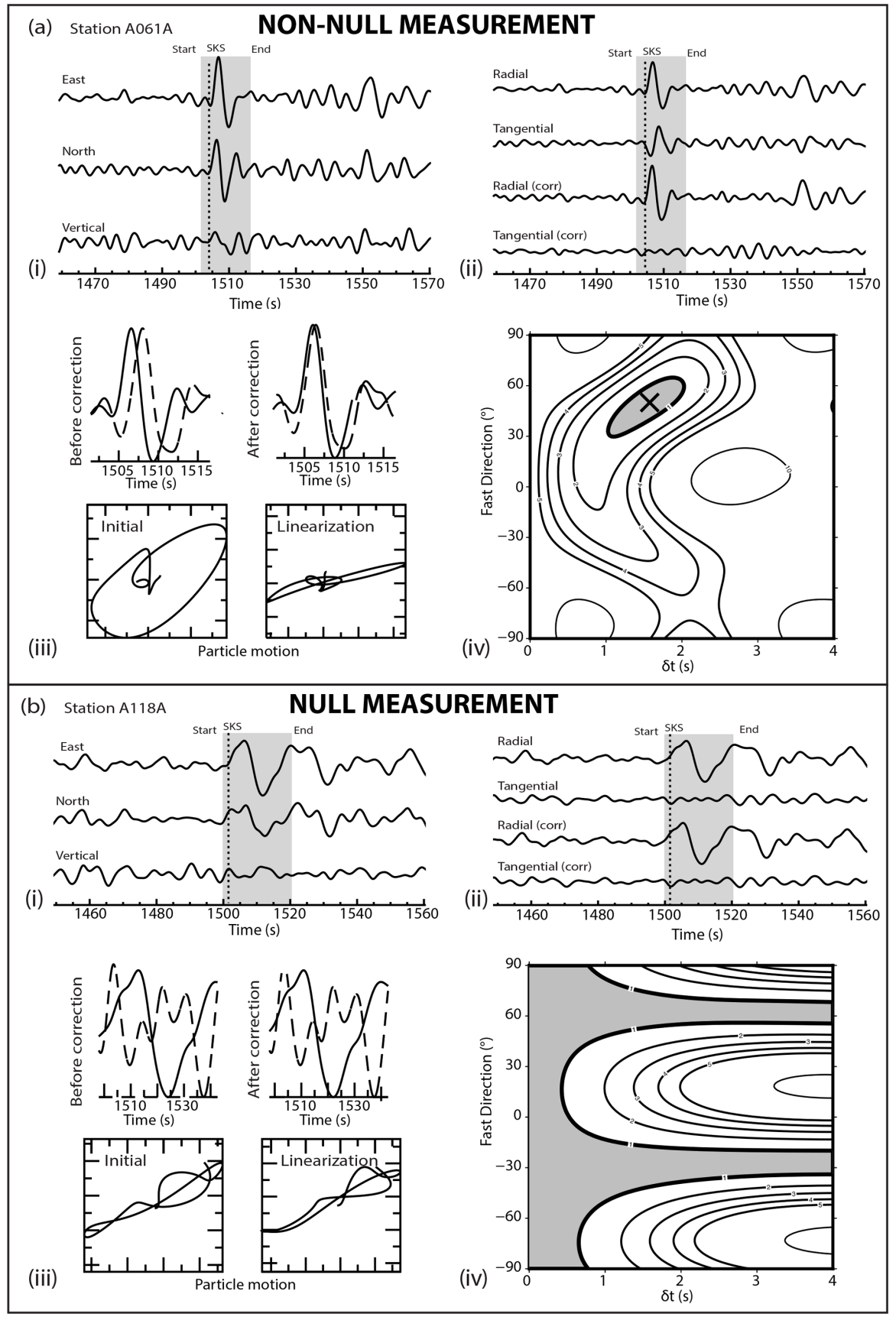

Figure 3. Examples of SKS analysis procedure for a successful SKS splitting measurement (a) and a situation where no energy is present on the tangential component, referred to as a null measurement (b). (i) Three-component seismograms recorded at station A061A, with the time window including SKS phase highlighted. (ii) The radial and tangential component seismograms, after rotation to the great circle arc (top two) and after the SKS splitting correction (bottom two). (iii) Top: time windows of the radial (black line) and tangential (dashed line) components showing the SKS phase before and after the correction. Bottom: particle motion before and after correction. (iv) Misfit contour surface showing the best solution pair of $\delta t$ and $\varphi$ (cross) and the $1 \sigma$ uncertainty surface (highlighted region).

the NE-SW observations in Germany change to a E-W average on the western side, in France. Here, measurements are more spatially heterogeneous: neighbouring stations record $\varphi$ axes almost $90^{\circ}$ different (Fig. 4a). South of the Alpine chain, in the Po Basin, SKS directions differ between west and east: fast axes display dominantly $\mathrm{N}-\mathrm{S}$ orientations in the western part of the basin, where the doubly verging Adriatic slabs meet the European slab. East of $\sim 10^{\circ}$ longitude, $\varphi$ directions become more scattered around the main NE-SW direction and tend to parallel the present-day plate bound- 
ary (Fig. 1). Delay time distributions do not have a particular pattern: higher values are located in the French part of the Western Alps and in southern Germany but also in the transition between Western Alps to Central Alps and the Po Basin. Local areas with $\delta t$ lower than $2 \mathrm{~s}$ are present in central Germany at the Moldanubian-Saxothuringian transition and part of the Po Basin.

Null measurements provide additional valuable information on the nature and distribution of anisotropy beneath the Alps. Figure $4 \mathrm{~b}$ shows the percentage value from the total number of viable SKS measurements at each station, as well as the direction of the incoming null SKS waves and their back-azimuthal coverage. Generally, stations with a small percentage of null measurements also yielded a large number of high-quality results and are mostly located in the Western Alps, Central Alps in their upper front, and the eastern Po Basin. Stations with a higher null percentage (between $50 \%$ to $100 \%$ ) are located in northern Switzerland (southwestern Molasse Basin) and in central Germany, at the MoldanubianSaxothuringian contact. At lower latitude (south and southeast of the Alpine Front) the number of null measurements decreases to lower than $50 \%$. The Alpine Front also marks a change in the dominant direction of the un-split SKS waves coming from the SW and NE in the northern region and dominantly NW south of the Front. These directions are similar to the estimated anisotropy fast axes throughout the region (Fig. 4a). This is expected since SKS waves polarized in the direction of anisotropy should not exhibit splitting. Events coming from $\mathrm{N}$ or $\mathrm{E}$ generally yield less null measurements (Fig. $4 \mathrm{~b}$ inset).

Distributions of $\varphi$ directions with respect to the backazimuth of their corresponding earthquake also reveal a few emerging patterns across the region (Fig. 4c). Most teleseismic events come from the SW and NE quadrants, yielding the most high-quality results in the western and central part of the study region. Projecting SKS fast axes at their $150 \mathrm{~km}$ piercing point depth would be expected to offset contrasting directions, if anisotropy was distributed laterally. However, in the French part of the Western Alps and west of the Rhine Graben, large single-station $\varphi$ variations belong to events coming from the same quadrant. In the Central Alps and part of central Germany, directions are more laterally coherent, closely following the NE-SW trend, irrespective of the event back-azimuth. The $\mathrm{N}-\mathrm{S} \varphi$ distribution is a secondary trend emerging in the Molasse Basin and is yielded by events coming from the SW (Fig. 4c). A smaller subset of SE and NW events are better recorded in the Eastern Alps but yield scattered $\varphi$ directions, including NE-SW, E-W, and NW-SE.

To better visualize the distribution of fast axes with respect to the event back-azimuth for stations located in different geographical positions, we plot examples of three representative high-quality station data (Fig. 4d). Station A061A, located in the central Swiss Alps, yields a homogeneous $\varphi$ distribution over the entire event back-azimuthal range, resulting in a small difference between the average circular value and the value obtained by misfit surface stacking (Fig. 4d). Station A037A is located at the transition between the Central Alps and the Eastern Alps, in western Austria, and yields a bimodal $\varphi$ distribution along a dominant NE-SW axis and a secondary $\mathrm{E}-\mathrm{W}$ direction. In this case a more evident difference in the mean values indicates a greater dispersion in the results. Station A300A, representative for the eastern Po Basin, yields high-quality measurements from events in the $45-100$ and $250-310^{\circ}$ back-azimuthal range, with the most frequent $\varphi$ along NE-SW. The average value calculated from circular statistics is different from that calculated with the stacking procedure, supporting an emerging trend of anisotropy heterogeneity towards the eastern part of the network.

Trends visualized in maps are even more evident in sections. Results from this study are averaged along with measurements from previous studies in $50 \mathrm{~km}$ by $50 \mathrm{~km}$, alongand off-plane distances, respectively. Variations of splitting parameters in the section quasi-parallel to the Alpine chain confirm the large-scale clockwise rotation of $\varphi$ axes from west to east, which is from -45 to $90^{\circ}$ over a $\sim 700 \mathrm{~km}$ distance (Fig. 5, section D). Sections perpendicular to the Alpine chain indicate more variability in $\varphi$ and $\delta t$. Section A crosses the Alps from SE to NW, starting from the northern termination of the Apennines, where $\varphi$ directions are $\sim-30^{\circ}$ and $\delta t$ ranges between 1-2.5 s. Across the western Po Basin two distinct distributions emerge, yielding a similar mean $\varphi$ value to the Apennines and variable $\delta t$ values. In the Southern Alps and Central Alps, separated by the Insubric Fault (Fig. 1), $\varphi$ directions are more homogenous, following the main NE-SW direction and $\delta t$ is between $0.5-1.5 \mathrm{~s}$. Across the European-Alpine Front and the Molasse Basin, $\varphi$ axes rotate from $\sim 50$ to $\sim 30^{\circ}$ and $\delta t$ increases above $1.5 \mathrm{~s}$. Stations in the Jura Mountains have more dispersed $\varphi$ values averaging around $45^{\circ}$ and $\delta t$ between $1.0-2.0 \mathrm{~s}$, and measurements become strongly scattered beneath the European Foreland in France. Sections B and C are both perpendicular to the Alpine chain, crossing the Po Basin, Southern Alps and Central Alps, and the Molasse Basin into Southern Germany. A common feature is that the distribution of fast axes is more coherent when entering the European foreland (EF) from the south, where the average value stabilizes around $45^{\circ}$ (section $\mathrm{B}$ ) and $\sim 60^{\circ}$ (section C). The onset of homogeneity, however, starts below the Central Alps in section B, while further east along section C, the Periadriatic Fault (Fig. 1) marks the transition from complex anisotropy to simple coherent measurements. In section $\mathrm{C}, \varphi$ in the European Foreland rotates from $\sim 60^{\circ}$ beneath the Molasse Basin to almost $90^{\circ}$ in southern Germany, across the Moldanubian and Saxothuringian terranes (Fig. 5). 

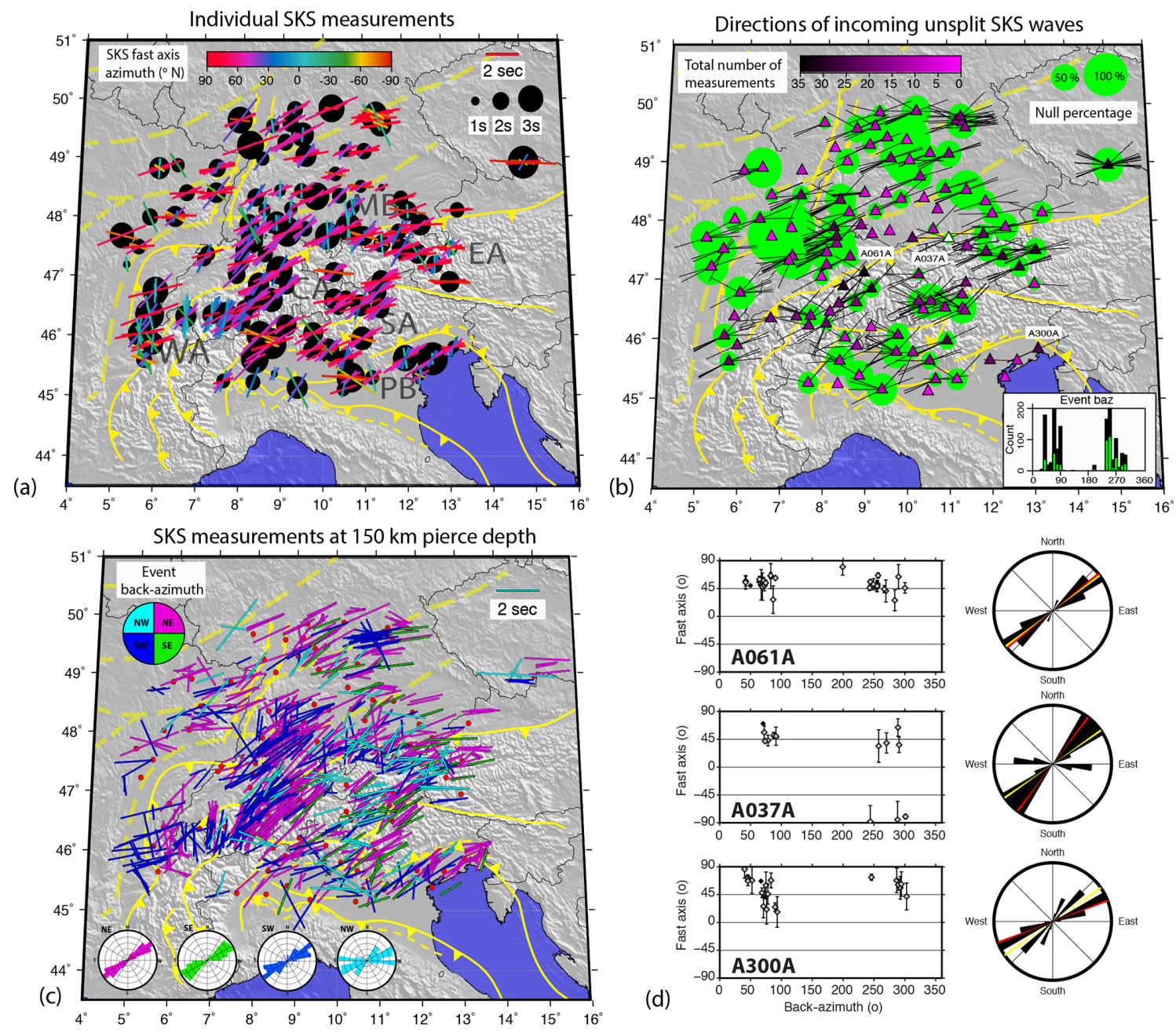

Figure 4. (a) Map of individual SKS fast-axis (bars) and time-delay (black circles) measurements at seismic stations. Colours represent SKS fast-axis back-azimuth. Yellow lines are major tectonic faults. Dashed yellow lines mark the limits of the Molasse and the Po sedimentary basins, respectively. (b) Map of the Alpine region comprising the percentage of null measurements (green circles) from the total number of measurements at each seismic station (coloured triangles). Bars indicate the direction of incoming SKS waves which yielded null measurements. Inset: histogram of high-quality earthquakes analysed in this study (black bars) and the number of null measurements (green bars) in $10^{\circ}$ back-azimuthal bins. (c) SKS measurements (bars) coloured with respect to the back-azimuth and shifted to the $150 \mathrm{~km}$ piercing point. Red points are the stations. Rose diagrams represent polar histograms of the SKS fast-axis directions for earthquakes coming from the NW, NE, SW, and SE, respectively. (d) Results at stations from different regions: A061A (Swiss Alps), A037A (Central Alps), and A300A (eastern Po Basin), also labelled in panel (b). Left: plots of the SKS fast-axis measurements versus back-azimuth. Right: normalized rose diagrams of SKS fast-axis directions, average SKS direction computed using the circular average (yellow), and the one obtained by stacking misfit surfaces from individual SKS splitting solutions (red).

\section{Discussion}

\subsection{Comparison with previous SKS splitting studies}

Our measurements of $\varphi$ and $\delta t$ are generally coherent, similar in magnitude and direction with previous studies of SKS anisotropy at neighbouring stations, and provide a smooth spatial continuity in the previously irregular measurement coverage (Figs. 5 and 6a). The average clockwise rotation of $\varphi$ directions from the Western Alps to the Central Alps are in agreement with results from Salimbeni et al. (2018) and
Barruol et al. (2011), although more significant single-station heterogeneity is displayed by stations located in the French Western Alps, implying more complex anisotropic structure in the deformed foreland European lithosphere than measurements in the Swiss Central Alps. Around $10^{\circ}$ longitude, the secondary $\mathrm{E}-\mathrm{W}$-trending $\varphi$ pattern becomes more evident in the Central Alps-Eastern Alps transition, as also noticed by Bokelmann et al. (2013) and Qorbani et al. (2015), although a more abrupt change was considered to occur at $\sim 13^{\circ}$, across the Tauern window in Austria. The ENE-SSW average mea- 

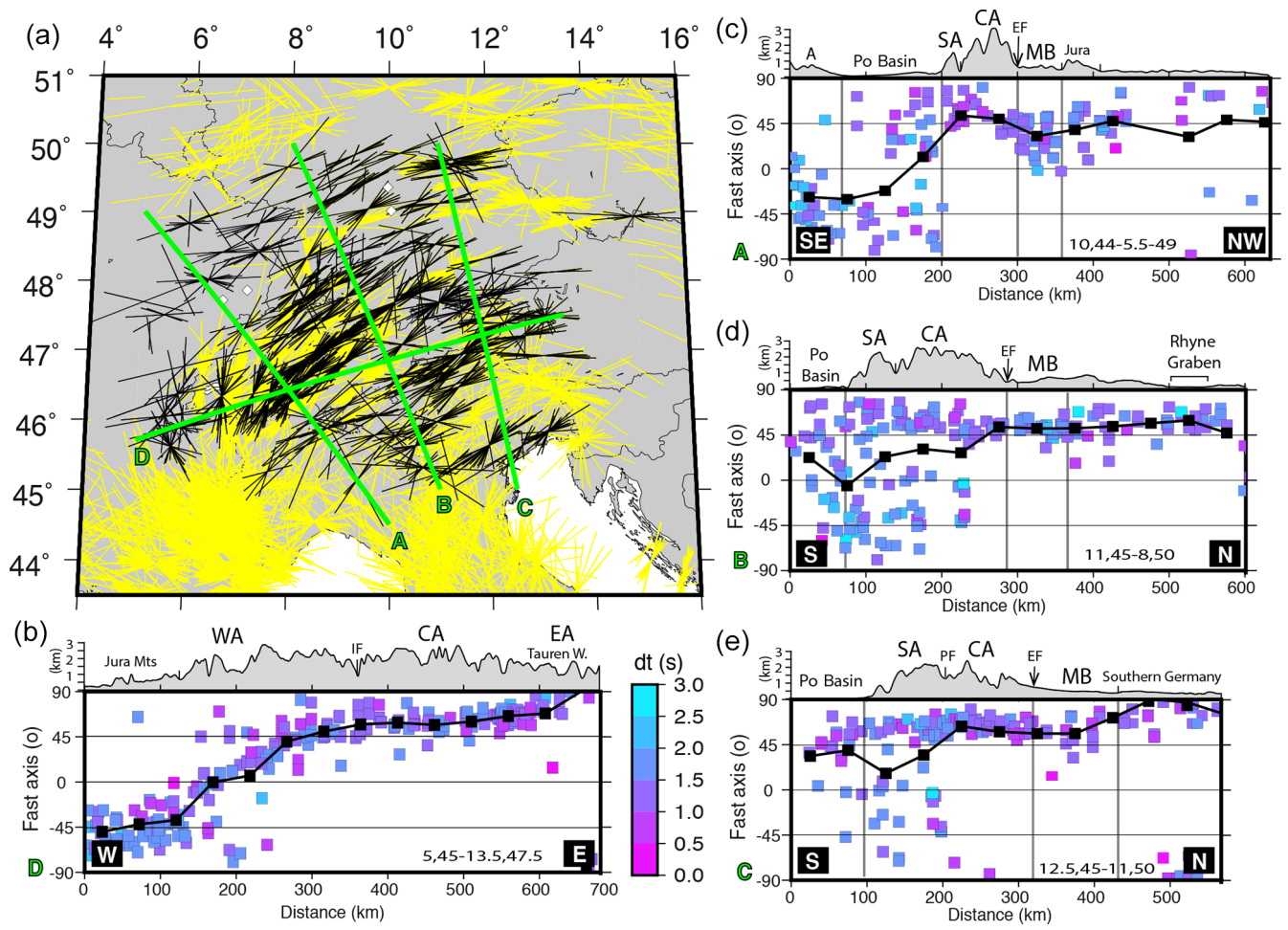

Figure 5. Sections of SKS splitting parameters across and along the Alpine orogen. (a) Map of western and central Europe showing past SKS results (yellow lines) and observations from this study (black lines). The green lines mark the locations of chosen sections. (b-e) Sections across and nearly along the orogen showing single-station SKS fast-axis direction variation within $\pm 50 \mathrm{~km}$ distance from the section. On top of each section, topography and the location of major geological units are reported: SA (Southern Alps), CA (Central Alps), WA (Western Alps), PF (Periadriatic Fault), IF (Insubric Fault), and AF (Alpine Front). Black squares are average $\varphi$ direction along the profile in $50 \mathrm{~km}$ distance intervals.

surements are also in agreement with the studies of Kummerow et al. (2006) and Bokelmann et al. (2013).

In the eastern Alpine region, in Austria and NE Italy, more heterogeneous $\varphi$ directions (Fig. 4) are similar to previous measurements (Salimbeni et al., 2013; Qorbani et al., 2015), where multilayer modelling suggested an interference between eastward-directed flow above a deeper detached Tethyan slab with intrinsic anisotropy (Qorbani et al., 2015). A secondary E-W fast anisotropy trend is also present in the eastern Southern Alps and the eastern Po Basin, similar to measurements by Salimbeni et al. (2013), who suggested that the juxtaposition of the Alpine and Dinaric mantle deformational fields may play a role in the detected $\varphi$ variations.

North of the Alpine Front, in the Molasse Basin and in the underlying Hercynian-aged SaxothuringianMoldanubian structures, our measurements are generally consistent both in $\varphi$ direction and delay times with the SKS parameters estimated at permanent and temporary stations in Germany (Bormann et al., 1996; Plenefisch et al., 2001; Walther et al., 2013). While the ESE-WNW direction is dominant, a progressive change in $\varphi$ directions across the Molasse Basin and the underlying SaxothuringianMoldanubian terranes, evident especially in section $\mathrm{C}$
(Fig. 5), has also been pointed out by Plenefisch et al. (2001). Some stations in the Saxothuringian-Moldanubian transition yielded only null measurements (Fig. 5), and a secondary N$\mathrm{S}$ trend also develops in the Molasse Basin, similar to one station analysed near the Rhine Graben by Walther et al. (2013).

\subsection{Depth and source of SKS anisotropy in the Alpine region}

A first-order indication of the depth of anisotropy or the path of the anisotropic SKS phase is the splitting delay time. The continental crust typically accounts for only $0.1-0.3 \mathrm{~s}$ (Silver, 1996) or 0.1-0.5 s (Barruol and Mainprice, 1993) contribution to the observed SKS splitting delay, which are incomparably smaller than our $\delta t$ values with a mean of $1.4 \mathrm{~s}$, requiring a mantle contribution. Furthermore, we can estimate the thickness of an anisotropic layer using the average $\delta t$ as $L=$ $\delta t \times \beta / k$ (Silver and Chan, 1988; Helffrich, 1995), where $\beta$ is the shear velocity $\left(4.48 \mathrm{~km} \mathrm{~s}^{-1}\right.$ in the upper mantle; Kennett et al., 1995) and $k$ is the average anisotropy percentage (4\% average in the upper $200 \mathrm{~km}$; Savage, 1999), yielding $\sim 160 \mathrm{~km}$ of possible anisotropic path length. This estimate exceeds the crustal or even lithospheric depths proposed in the Alps (between 80 and $110 \mathrm{~km}$; Miller and Agostinetti, 

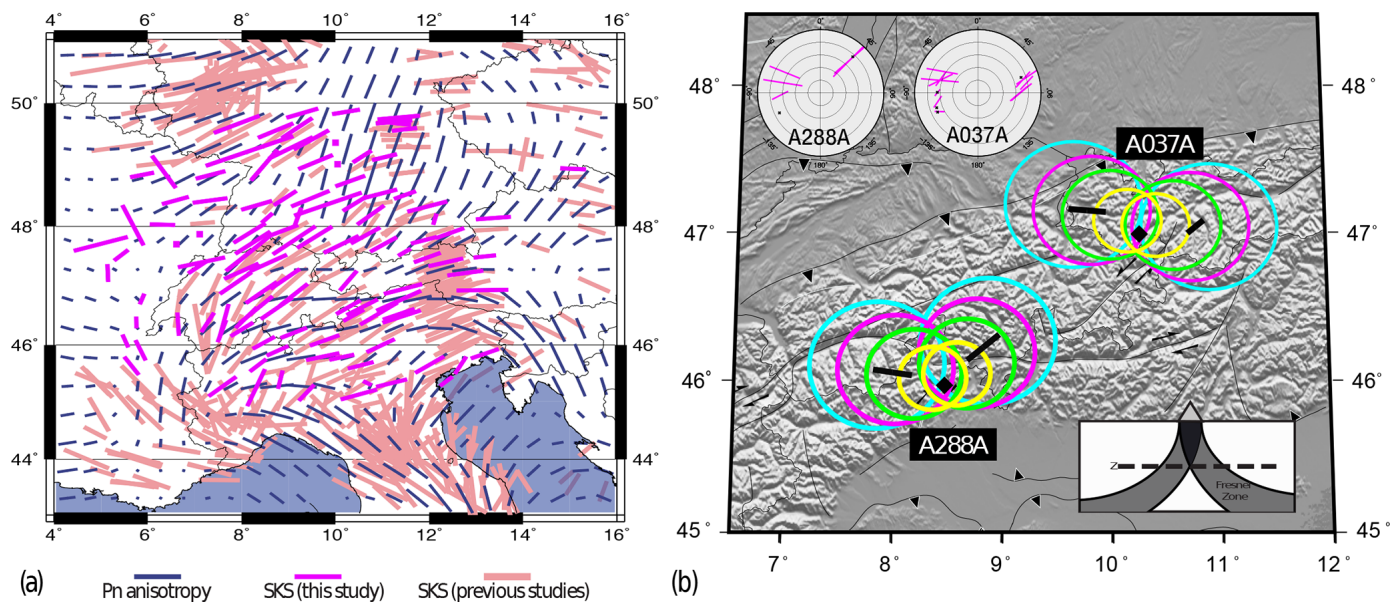

Figure 6. (a) Comparison between our SKS measurements (red bars), Pn anisotropy axes (Diaz et al., 2012, and references therein), and previous SKS measurements. (b) Single-station Fresnel analysis of SKS observations at two AlpArray seismic stations from two earthquakes from opposing directions. Coloured circles show the approximate Fresnel zone for the SKS wave at different depths: $50 \mathrm{~km}$ (yellow), $100 \mathrm{~km}$ (green), $150 \mathrm{~km}$ (magenta), and $200 \mathrm{~km}$ (cyan). Black lines show the SKS fast-axis direction projected at its $150 \mathrm{~km}$ piercing point. Top left insets: polar plots for all measurements available for the two stations. Bottom right inset: cross section of the Fresnel zones of two incoming SKS waves from opposing directions and the depth where these zones overlap (after Alsina and Snieder, 1995).

2012; Geissler et al., 2010; Bianchi et al., 2014), suggesting that the SKS signal may either represent asthenospheric flow beneath the orogen, or it is a combination of lithospheric deformation and underlying mantle flow.

Most collisional orogenic systems are characterized by anisotropy that aligns with the structural grain of the belt and has often been considered to reflect asthenospheric flow due to collision (e.g. Meissner et al., 2002) or a signature of combined asthenospheric origin and vertically coherent deformation within the lithosphere (Wang et al., 2008; Chang et al., 2015; Kuo et al., 2018). To better constrain the depth and eventually the vertical coherency of the anisotropy sampled by SKS, we compare our measurements with the direction of the anisotropy described by the Pn phase (Diaz et al., 2012), which propagates along the Moho interface and is indicative of subcrustal anisotropic properties (Fig. 6). SKS fast-axis directions are somewhere similar to Pn anisotropy in the Western Alps to Swiss Central Alps, Southern Alps, and Eastern Alps and partially in the Molasse Basin but disagree with it north of $\sim 47^{\circ}$ latitude and in northeast France. In addition, an ambient noise study of azimuthal anisotropy in the Swiss Alps (Fry et al., 2010) detected a change in anisotropy orientation from orogen-parallel within the crust to orogen-perpendicular directions at lower crustal depths. If the equivalent anisotropic layer thickness is $\sim 160 \mathrm{~km}$ and lithospheric thickness is $\sim 80 \mathrm{~km}$ in the area, at least part of the SKS anisotropic path must reside in the lithosphere. However, at least in the central (Swiss) Alpine region, the lack of back azimuthal variation in SKS observations at single stations (Fig. 4) is not consistent with multiple layers of anisotropy, but it is rather indicative of simple asthenospheric flow and/or a coupled lithosphere-asthenosphere deformation, with an unchanged anisotropy with depth.

The approximate source depth of anisotropy can also be estimated by evaluating the possible overlap of SKS Fresnel zones at a certain range of depths (Alsina and Snieder, 1995). The radius of the Fresnel zone, $R_{\mathrm{f}}$, can be estimated from the main period of the SKS phase, $T$ (here equal to $10 \mathrm{~s}$ ), the S-wave velocity $v$ at depth $h$, and the angle of incidence $\theta$ as

$R_{\mathrm{f}}=\sqrt{(T v h / 2 \cos (\theta)}$

(e.g. Pearce and Mittleman, 2002; Margheriti et al., 2003). The depth at which Fresnel zones of SKS phases coming from opposite directions overlap is usually interpreted to show an upper bound for the anisotropy source. Figure $6 \mathrm{~b}$ shows examples of Fresnel zones for two AlpArray stations that show anomalous SKS observations with respect to the surrounding stations. Fresnel analysis at both stations shows that Fresnel zones for two opposite SKS waves intersect at least down to $\sim 200 \mathrm{~km}$, suggesting that different anisotropic sources must reside below this depth. At station A288A, in the Southern Alps, south of the Insubric Fault, the geological suture between Europe and Adria, Fresnel zones at $200 \mathrm{~km}$ still partially overlap, suggesting an even deeper source in this region. Here, estimates of the lithosphere-asthenosphere boundary (LAB) depth show a lithospheric thickness of $140 \mathrm{~km}$ (Miller and Agostinetti, 2012) at the approximate location of A288A. In contrast, LAB depths at station A037A are shallower, with estimates between 70-90 km (Bianchi et al., 2014) and 100-120 km (Geissler et al., 2010). In both sites we can infer a lateral variation in the anisotropy pattern below LAB. 
A quick comparison between $\mathrm{LAB}$ depth variations in the Alpine region and delay times does not yield a clear correlation, which should also support a non-lithospheric source signal. Most S-receiver function-based LAB estimates generally indicate $\mathrm{LAB}$ depths in the $90-140 \mathrm{~km}$ range beneath the Alps (Geissler et al., 2010; Miller and Agostinetti, 2012; Bianchi et al., 2014), decreasing to $80-100 \mathrm{~km}$ north of the European Front (Geissler et al., 2010). In contrast, Plomerová and Babuska (2010) infer lithospheric thicknesses of up to $230 \mathrm{~km}$ beneath the Alps and $\sim 100 \mathrm{~km}$ north of the front. LAB estimates thus vary between studies and the actual boundary remains elusive, especially in on-slab locations, where slabs plunge almost vertically, but a large-scale decrease towards the north is a common feature. However, delay time variability (Fig. 4a) does not mirror this largescale decrease, providing further support for an asthenospheric source.

\subsection{Comparison with tomography: relationships with slabs and circum-Alpine seismic anomalies}

To understand how deeper upper-mantle structure may be connected with SKS observations, we also test for correspondence between our measurements and 3D seismic heterogeneities (Fig. 7). A high-Vp anomaly, often interpreted as the southward-plunging European slab, lies beneath the Alpine chain obliquely (Fig. 1), extending under the western Po Basin, Southern Alps, Central Alps, and Eastern Alps down to $\sim 300 \mathrm{~km}$ (Lippitsch et al., 2003; Piromallo and Morelli, 2003; Giacomuzzi et al., 2011; Zhu et al., 2015; Zhao et al., 2016). Stations in the Western Alps, part of the Central Alps, and the Molasse Basin are underlain by negative $\mathrm{Vp}$ anomalies and are usually interpreted to be located on the forearc side of the southward-plunging European slab. SKS parallel the trend of the positive anomaly and do not seem to change directions across its boundaries. We chose to interpret our observations in relation to the most recent seismic tomography of Europe (Zhu et al., 2015), especially because the model incorporates azimuthal anisotropy parameters. Purely isotropic velocity models are prone to contamination with artefact anomalies, where anisotropy has not been taken into account (e.g. Bezada et al., 2016).

Surveys of crustal structure and upper-mantle tomography images of the Alpine chain led to a different interpretation for the origin of the Alpine slab beneath the Eastern Alps, suggesting that a lithospheric fragment lithologically linked to the Adria plate dips northward beneath the eastern section of the orogen (Lippitsch et al., 2003; Handy et al., 2015). A switch in subduction polarity is thus expected at the transition between the Western Alps and Eastern Alps (around $10-11^{\circ} \mathrm{E}$ ). However, there is no marked change in SKS anisotropy at that longitude, except for a progressive clockwise reorientation of the SKS axes (Fig. 5), which broadly follow the orogenic trend and parallel the strike of the positive seismic velocity anomalies. The secondary E-W $\varphi$ distribution (Fig. 4) appears at stations located east of $10^{\circ}$ longitude, at the border between Switzerland, Austria, and NE Italy. Bokelmann et al. (2013) also identifies a change in SKS directions, although the onset of this trend is placed more eastward across the Tauern window, where the Adriatic indenter is known to act towards the N-NE (Bus et al., 2009), actively causing tectonic escape of the Eastern Alpine units (Kummerow et al., 2006). While SKS patterns are not sufficient evidence to support a hypothetical switch in subduction polarity at $10-11^{\circ}$, the subtle change in single-station individual SKS $\varphi$ patterns implies a change in mantle deformation styles at this longitude, either due to escape mechanisms or the influence of a more complex slab structure beneath.

In the western Po Basin, multiple positive seismic velocity anomalies coalesce (Fig. 7), which is likely the signature of the complex interaction between the subducted northwestern segment of Adria and the southeastward-plunging European lithosphere. Here, measurements are more heterogeneous (Fig. 4), probably indicating complex and reduced flow patterns due to the presence of multiple subductions and a strongly reduced supra slab space (Fig. 8). $\varphi$ directions show a transition from the typical central Alpine NE-SW trend towards a N-S orientation that continues into the Apennines (Fig. 5). In the eastern Po Basin, low negative seismic anomalies, coupled with high subsidence rates and isostasy imbalance estimates, pointed out a possible asthenospheric downwelling mechanism (Faccenna et al., 2014). However, vertical movement of mantle material would have a significant effect on SKS measurements (e.g. Xue and Allen, 2005; Levin et al., 2018; Petrescu et al., 2020). Vertically oriented deformation in the upper mantle would be transparent to the nearly vertical propagation path of SKS phases, whose particle motion samples the horizontal azimuthal anisotropy. Our SKS measurements in the eastern Po Basin are especially devoid of null measurements (Fig. 4b) and thus do not support this hypothesis; on the contrary, here it is possible to assume that the supra European slab space is large enough to host the eastward mantle flow coming from beneath the Apennines (Fig. 8), which is in agreement also with previous possible flow scenarios (Király et al., 2018, and references therein).

\subsection{Extent of asthenospheric flow in response to collision north of the Alpine Front}

Most SKS observations from the high-topography region south of the Alpine Front are interpreted as collision-related asthenospheric flow developing an A-type olivine fabric (Barruol et al., 2011; Bokelmann et al., 2013; Qorbani et al., 2015). While this explanation may be justified in a region of recent orogenic activity, the similarity between SKS measurements north of the Alpine Front and those south of it (Fig. 5) begs the question of whether anisotropy beneath stable Europe is still related to the Alpine orogeny and the vertically plunging slabs act as flow barriers (Fig. 8). North and northwest of the Alpine Front, the European lithosphere suf- 
(a)

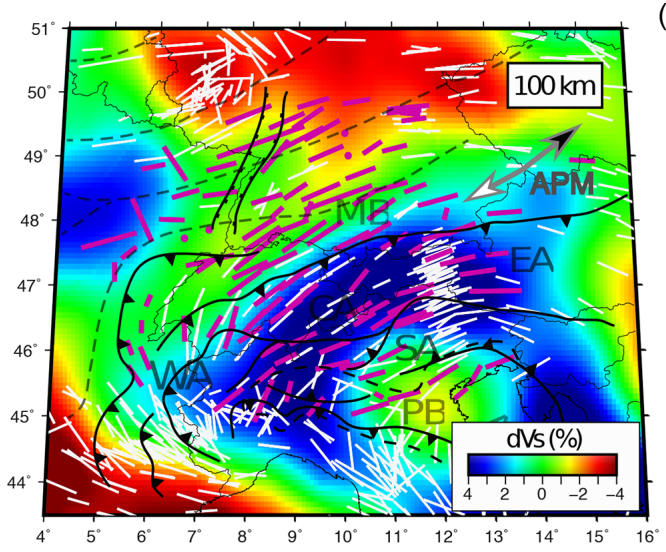

(c)

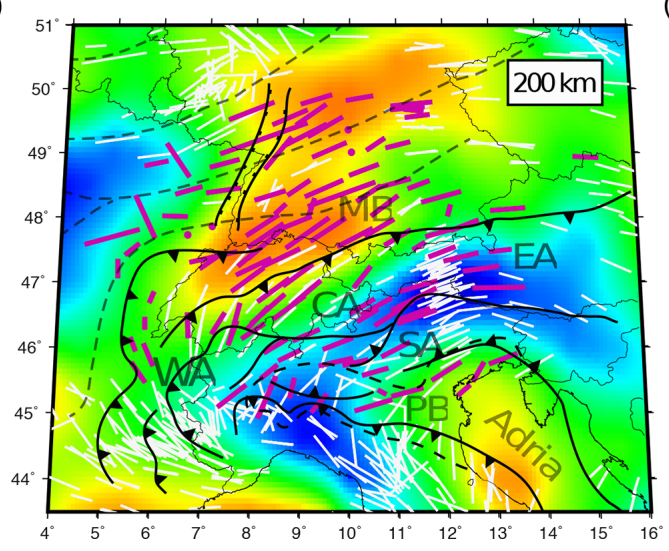

(b)

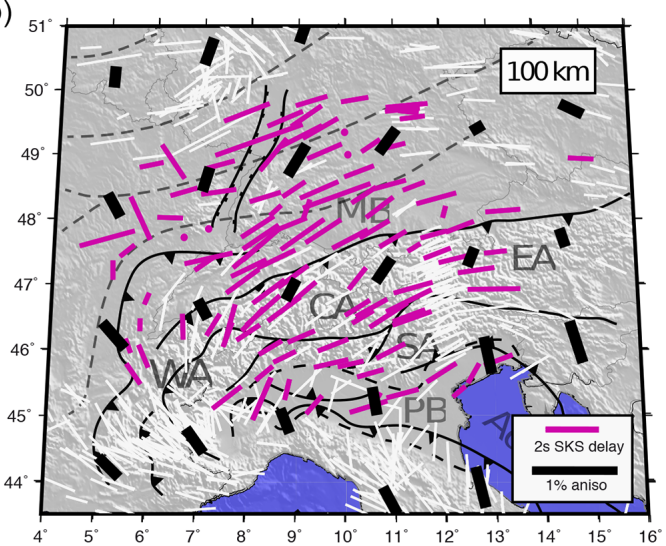

(d)

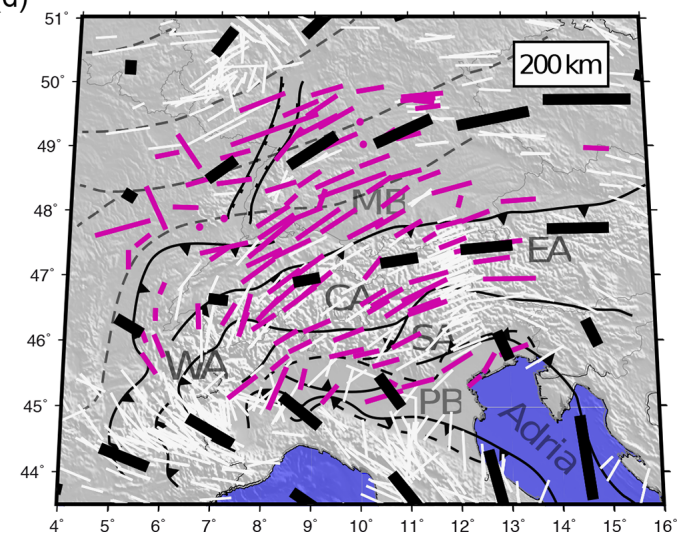

Figure 7. (a, c) The comparison of SKS results with the seismic tomography model by Zhu et al. (2015) at $100 \mathrm{~km} \mathrm{(a)} \mathrm{and} 200 \mathrm{~km}$ (c). Magenta lines are SKS fast axes and delay times obtained in this study, while white bars are previous measurements (Salimbeni et al., 2008, 2013; Barruol et al., 2011; Kummerow et al., 2006; Bokelmann et al., 2013; Qorbani et al., 2016). In the $100 \mathrm{~km}$ slice map, also absolute plate motion (APM) is reported: the black arrowhead represents the EU plate motion in no net rotation (NNR) system for GSRMv2.1, ITRF2014[2016], and HS3-NUVEL1A; the white arrowhead is again the EU plate motion direction in the "Hot Spot" reference system valid for HS3-Nuvel1 (Kreemer et al., 2014; Altamimi et al., 2016; Gripp and Gordon, 2002). (b, d) The comparison of SKS results from this study and previous measurements with azimuthal anisotropy percentages (black bars) estimated by Zhu et al. (2015) at $100 \mathrm{~km}$ (b) and $200 \mathrm{~km}$ (d), respectively.
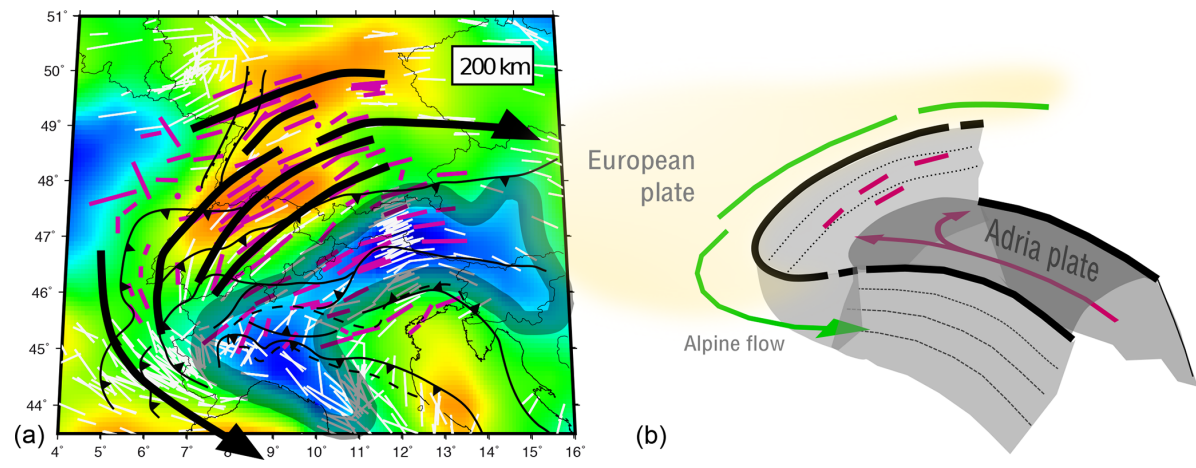

Figure 8. (a) Seismic tomography model of the Alpine region at $200 \mathrm{~km}$ depth from Zhu et al. (2015) with overlain SKS measurements (white - previous studies, pink - this study). Black arrows are the authors' interpretation of a possible mantle flow around the barrier slabs (outlined with a thick grey line). (b) Sketch of possible mantle flow patterns based on our SKS measurements, indicating the possible barrier effect of the Alpine and Adria slabs. 
fered pre-Alpine deformation during the Hercynian Orogeny with remnant sutures trending along an approximate WSWENE direction (Fig. 1). The most recent phases of extension affecting the Rhine Graben follow the same orientation as the Hercynian surface geologic trends (e.g. Schumacher, 2002), raising the possibility that anisotropy measurements here also record more recent lithospheric extension, as also proposed by Walther et al. (2013).

North of the Alpine Front, our measured SKS fast-axis directions parallel both surface geological structures (Fig. 4) and absolute plate motion direction in a no-net rotation frame (Fig. 7; GSRMv2.1 - Kreemer et al., 2014; ITRF2014 Altamimi et al., 2016; HS3-NUVEL1A - Gripp and Gordon, 2002) and are perpendicular to maximum horizontal stress (oriented mostly NNW-SSE; Heidbach et al., 2018). However, LAB depths beneath the Molasse Basin are too shallow (80-100 km; Geissler et al., 2010) compared to the anisotropic layer thickness estimated from delay times ( $\sim 170 \mathrm{~km})$ to justify a purely lithospheric contribution to the observed anisotropy. Fresnel arguments support that the strongest anisotropy may be located below $\sim 200 \mathrm{~km}$ depth, where it varies laterally. The slow-speed plate motion may be insufficient to induce coherent basal drag mineral fabrics (Debayle and Ricard, 2013), so we can discard the influence of absolute plate movement as well. Moreover, the crustal contribution is too small to be taken into consideration (Barruol and Mainprice, 1993), and the discrepancy between Pn anisotropy mostly sensitive to lower-crustal and sub-Moho depth ranges and our SKS measurements (Fig. 6) further supports a deeper source for the latter. Therefore, anisotropy beneath the circum-Alpine region has a clear sublithospheric contribution and most probably reflects the effect of Alpine collision, suggesting the presence of vertical slabs beneath the Alps that control asthenospheric flow for a few hundred $\mathrm{km}$ beneath the European foreland (Fig. 8). The change in SKS fast polarizations across the Alpine Front, however, is more significant further west in profile A (Fig. 5), where homogeneously distributed anisotropy observations in the Swiss Alps switch into the less coherent directions estimated at stations west of the Rhine Graben (Fig. 4). Up to $90^{\circ}$ $\varphi$ changes occur in the proximity of a fast seismic anomaly that develops in northeast France (Fig. 7). This upper-mantle anomaly, possibly a remnant Hercynian lithospheric root, may be affecting the surrounding flow, interacting with the barrier flow-field created by the Alpine slabs. It is worth noting that part of the fast azimuths parallel to the Alpine chain could be explained also by the fabrics present within the vertically dipping mantle lithosphere and the entrained asthenospheric mantle. The mantle portions should then be characterized by a dip-parallel foliation containing the $a$ and $c$ axes of olivine, a mechanism that has been proposed to explain the trench-parallel fast azimuths along subduction zone forearcs (Song and Kawakatsu, 2012). Alternatively, the trenchparallel azimuths could in part be interpreted by the formation of B-type fabrics (Jung et al., 2006) in highly stressed regions of the collision zone close to the $\mathrm{LAB}$, which are however spatially limited. The occurrence of C- and E-type olivine fabrics requires the presence of water in the mantle, which is at odds with the sparse volcanism and magma compositions recorded in the area.

Further north in central Germany, across the MoldanubianSaxothuringian boundary, average SKS directions rotate clockwise by $\sim 40^{\circ}$ (Fig. 5, profile C). Plenefisch et al. (2001) also observed a rotation in fast axes across the Moldanubian to Saxothuringian terranes, interpreting it as evidence that the boundary extends to lithospheric depths. At this distance, SKS observations can partially contain a lithospheric palaeodeformational signature (e.g. Babuska and Plomerová, 2006). However, LAB depths here are $\sim 100$ $120 \mathrm{~km}$ (Geissler et al., 2010; Plomerová and Babuska, 2010), indicating a $60-80 \mathrm{~km}$ mantle lithosphere, assuming an average crustal thickness of $40 \mathrm{~km}$. This is still too small to account for the observed splitting delay times (Fig. 4), suggesting SKS anisotropy has a clear asthenospheric contribution, perhaps not related to Alpine or Hercynian deformation. As Bormann et al. (1996) also pointed out, seismically estimated temperatures at lithospheric depths may be too high to allow for the development and long-time preservation of fossil anisotropy. The European lithosphere suffered thermal thinning due to Cenozoic rifting and possible mantle plume activity connected to the Atlantic plume system (e.g. Goes et al., 1999; Dèzes et al., 2004), whose far-field influence may start to be manifested here.

\section{Conclusions}

To place constraints on the mantle deformation beneath the Central Alps and the greater Alpine region, we analyse SKS splitting at 113 new broadband seismic stations belonging to the AlpArray seismic experiment and permanent stations in Italy, Austria, Switzerland, France, and Germany. SKS directions are mostly parallel to the orogenic strike and the trend of the subducted slabs beneath the Alpine chain, rotating clockwise from -45 to $90^{\circ}$ from west to east. Splitting delay times averages to $\sim 1.4 \mathrm{~s}$ and are mainly representative of active asthenospheric flow around the plunging Alpine slabs. There is no large-scale change in SKS directions or delay times at the location of a putative subduction polarity switch beneath the Central Alps, although we note a certain subtle change in anisotropy complexity. Simple flow or a coupled lithosphere-asthenosphere deformation may dominate the mantle beneath the central Swiss Alps, where directions follow a consistent NE-SW trend, while more complex structures develop beneath the Eastern Alps, in agreement with previous studies on this region and further east. In the Po Basin SKS directions differ between west and east: fast axes have prevailing $\mathrm{N}-\mathrm{S}$ orientations in the western part beneath which opposite Adriatic flanks meet the European slab. East of $\sim 10^{\circ}$ longitude, SKS directions 
become more scattered around the main NE-SW trend and do not support a presumed asthenospheric downwelling related to the subduction of Adria. North of the Alpine Front, orogen-parallel anisotropy persists, implying that the effect of the Alpine slabs acting as flow barriers extends far beneath the foreland. At the contact between the Moldanubian and Saxothuringian terranes, sutured during the Hercynian Orogeny, directions experience an almost $40^{\circ}$ rotation. However, the thin lithosphere beneath the region is insufficient to account for the observed splitting delay time. Therefore, we interpret anisotropy there as asthenospheric and that it may start to feel the influence of mantle processes unrelated to past Hercynian deformation, crustal extension, or the indentation of Adria. To the west of the Rhine Graben, in northeast France, a strong positive seismic anomaly is located at uppermantle depths and SKS anisotropy measurements are highly variable in its proximity, suggesting a local perturbation in the flow field in the greater Alpine region.

Data availability. The results of this paper are all available in the tables included in the Supplement (see below). Original seismograms from AlpArray temporary stations can be found at the following DOI: https://doi.org/10.12686/alparray/z3_2015 (AlpArray Seismic Network, 2015). Data from permanent stations used in this study were obtained from multiple network archives: the Italian National Seismic Network (https://doi.org/10.13127/SD/ X0FXnH7QfY, INGV Seismological Data Centre, 2006), the Swiss Seismological Network (https://doi.org/10.12686/sed/networks/ch, Swiss Seismological Service (SED) at ETH Zurich, 1983), the German Regional Seismic Network (https://doi.org/10.25928/mbx6hr74, BGR SZO Data Center, 2020), the French National Seismic Network (https://doi.org/10.15778/RESIF.FR, French National Seismic Network, 2020), and the Province Sudtirol seismic network (SI, http://cnt.rm.ingv.it/en/instruments/network/SI, Istituto Nazionale di Geofisica e Vulcanologia, 2020).

Supplement. Tables of original measurements and average values discussed in this paper are included as Table S1 for no-null measurements, Table S2 for null measurements, and Table S3 for average values. The supplement related to this article is available online at: https://doi.org/10.5194/se-11-1275-2020-supplement.

Team list. The complete member list of the AlpArray Working Group can be found at http://www.alparray.ethz.ch.

Author contributions. LP made most of the measurements, prepared the visualisation of all results, and prepared the article. SP and SS formulated the study, made part of the measurements and visualisations, and prepared the discussion. MF supervised all of the study and contributed to discussion and fund acquisition.
Competing interests. The authors declare that they have no conflict of interest.

Acknowledgements. Laura Petrescu was supported by the European Research Council project Newton Grant agreement 758199, under H2020-EU.1.1. Most figures were made using the GMT software (Wessel and Smith, 1998).

Financial support. This research has been supported by the European Commission, H2020 Research Infrastructures (NEWTON (grant no. 758199)).

Review statement. This paper was edited by Caroline Beghein and reviewed by three anonymous referees.

\section{References}

Allen, P. A., Homewood, P., and Williams, G. D.: Foreland basins: An introduction, in: Foreland basins: International Association of Sedimentologists Special Publication 8, edited by: Allen, P. A. and Homewood, P., 3-12, 1986.

AlpArray Seismic Network: AlpArray Seismic Network (AASN) temporary component, AlpArray Working Group, Other/Seismic Network, https://doi.org/10.12686/alparray/z3_2015, 2015.

Alsina, D. and Snieder, R.: Small-scale sublithospheric mantle deformation: constraints from SKS splitting observations, Geophys. J. Int., 123, 431-448, 1995.

Altamimi, Z., Rebischung, P., Métlvler, L., and Collilleux, X.: ITRF2014: A new release of the International Terrestrial Reference Frame modeling nonlinear station motions, J. Geophys. Res., 121, 6109-6131, https://doi.org/10.1002/2016JB013098, 2016.

Babuska V. and Plomerová, J.: European mantle lithosphere assembled from rigid microplates with inherited seismic anisotropy, Phys. Earth Planet. In., 158, 264-280, https://doi.org/10.1016/j.pepi.2006.01.010, 2006.

Baccheschi, P., Margheriti, L., and Steckler, M.: Seismic anisotropy reveals focused mantle flow around the Calabrian slab (Southern Italy), Geophys. Res. Lett., 34, L05302, https://doi.org/10.1029/2006GL028899, 2007.

Barruol, G. and Hoffmann, R.: Upper mantle anisotropy beneath the Geoscope stations, J. Geophys. Res., 104, 10757-10773, 1999.

Barruol, G. and Mainprice, D.: A quantitative evaluation of the contribution of crustal rocks to the shear-wave splitting of teleseismic SKS waves, Phys. Earth Planet. In., 78, 281-300, 1993.

Barruol, G., Bonnin, M., Pedersen, H., Bokelmann, G. H., and Tiberi, C.: Belt-parallel mantle flow beneath a halted continental collision: The Western Alps, Earth Planet. Sc. Lett., 302, 429438, https://doi.org/10.1016/j.eps1.2010.12.040, 2011.

Bezada, M., Faccenda, M., and Toomey, D.: Representing anisotropic subduction zones with isotropic velocity models: A characterization of the problem and some steps on a possible path forward, Geochem. Geophy. Geosy., 17, 3164-3189, https://doi.org/10.1002/2016GC006507, 2016. 
Bianchi, I., Miller, M. S., and Bokelmann, G.: Insights on the upper mantle beneath the Eastern Alps, Earth Plan. Sc. Lett., 403, 199209, https://doi.org/10.1016/j.epsl.2014.06.051, 2014.

Bokelmann, G., Qorbani, E., and Bianchi, I.: Seismic anisotropy and large-scale deformation of the Eastern Alps, Earth Planet. Sc. Lett., 383, 1-6, https://doi.org/10.1016/j.eps1.2013.09.019, 2013.

Bormann, P., Grünthal, G., Kind, R., and Montag, H.: Upper mantle anisotropy beneath central Europe from SKS wave splitting: effects of absolute plate motion and lithosphereasthenosphere boundary topography?, J. Geodyn., 22, 11-32, https://doi.org/10.1016/0264-3707(96)00014-2, 1996.

Buontempo, L., Bokelmann, G., Barruol, G., and Morales, J.: Seismic anisotropy beneath southern Iberia from SKS splitting, Earth Planet. Sc. Lett., 273, 237-250, https://doi.org/10.1016/j.epsl.2008.06.024, 2008.

Bus, Z., Grenerczy, G., Táoth, L., and Máonus, P.: Active crustal deformation in two seismogenic zones of the Pannonian region - GPS versus seismological observations, Tectonophysics, 474, 343-352, https://doi.org/10.1016/j.tecto.2009.02.045, 2009.

Chang, L., Flesch, L. M., Wang, C.-Y., and Ding, Z.: Vertical coherence of deformation in lithosphere in the eastern Himalayan syntaxis using GPS, Quaternary fault slip rates, and shear wave splitting data, Geophys. Res. Lett., 42, 5813-5819, https://doi.org/10.1002/2015GL064568, 2015.

Civello, S. and Margheriti, L.: Toroidal mantle flow around the Calabrian slab (Italy) from SKS splitting, Geophys. Res. Lett., 31, L10601, https://doi.org/10.1029/2004GL019607, 2004.

Coward, M. and Dietrich, D.: Alpine tectonic overview, Geol. Soc. Lond. Spec. Publ., 45, 1-29, https://doi.org/10.1144/GSL.SP.1989.045.01.01, 1989.

Eakin, C. M., Wirth, E. A., Wallace, A., Ulberg, C. W., Creager, K. C., and Abers, G. A.: SKS splitting beneath Mount St. Helens: Constraints on sub slab mantle entrainment, Geochem. Geophy. Geosy., 20, 4202-4217, https://doi.org/10.1029/2019GC008433, 2019.

Darbyshire, F. A., Bastow, I. D., Forte, A. M., Hobbs, T. E., Calvel, A., Gonzalez-Monteza, A., and Schow, B.: Variability and origin of seismic anisotropy across eastern Canada: Evidence from shear wave splitting measurements, J. Geophys. Res.-Sol. Ea., 120, 8404-8421, https://doi.org/10.1002/2015JB012228, 2015.

Davis, J. C.: Statistics and data analysis in geology, 3rd Edn., Wiley, ISBN 978-0-471-17275-8, 2002.

Debayle, E. and Ricard, Y.: Seismic observations of large-scale deformation at the bottom of fast-moving plates, Earth. Planet. Sc. Lett., https://doi.org/10.1016/j.eps1.2013.06.025, 2013.

Dèzes, P., Schmid, S., and Ziegler, P.: Evolution of the European Cenozoic Rift System: interaction of the Alpine and Pyrenean orogens with their foreland lithosphere, Tectonophys., 389, 133, https://doi.org/10.1016/j.tecto.2004.06.011, 2004.

Diaz, J., Gallart, J., Villasenõr, A., Mancilla, F., Pazos, A., Córdoba, D., Pulgar, J., Ibarra, P., and Harnafi, M.: Mantle dynamics beneath the Gibraltar Arc (western Mediterranean) from shearwave splitting measurements on a dense seismic array, Geophys. Res. Lett., 37, https://doi.org/10.1029/2010GL044201, 2010.

Diaz, J., Gil, A., and Gallart, J.: Uppermost mantle seismic velocity and anisotropy in the Euro-Mediterranean region from Pn and Sn tomography, Geophys. J. Int., 192, 310-325, https://doi.org/10.1093/gji/ggs016, 2012.
Faccenna, C., Becker, T. W., Miller, M. S., Serpelloni, E., and Willett, S. D.: Isostasy, dynamic topography, and the elevation of the Apennines of Italy, Earth Planet. Sc. Lett., 407, 163-174, 2014.

Fouch, M. J. and Rondenay, S.: Seismic anisotropy beneath stable continental interiors, Phys. Earth Planet. Int., 158, 292-320, https://doi.org/10.1016/j.pepi.2006.03.024, 2006.

French National Seismic Network: RESIF and other Broadband and accelerometric permanent networks in metropolitan France, RESIF, https://doi.org/10.15778/RESIF.FR, last access: 1 July 2020.

Froitzheim, N., Plasienka, D., and Schuster, R.: Alpine tectonics of the Alps and Western Carpathians, Geology of Central Europe, 2, 1141-1232, 2008.

Fry, B., Deschamps, F., Kissling, E., Stehly, L., and Giardini, D.: Layered azimuthal anisotropy of Rayleigh wave phase velocities in the European Alpine lithosphere inferred from ambient noise, Earth Planet. Sc. Lett., 297, 95-102, https://doi.org/10.1016/j.epsl.2010.06.008, 2010.

Geissler, W. H., Sodoudi, F., and Kind, R.: Thickness of the central and eastern European lithosphere as seen by $\mathrm{S}$ receiver functions, Geophys. J. Int., 181, 604-634, https://doi.org/10.1111/j.1365246X.2010.04548.x, 2010.

German Regional Seismic Network (GRSN): fdsnws-station, BGR SZO Data Center, https://doi.org/10.25928/mbx6-hr74, last access: 1 July 2020.

Giacomuzzi, G., Chiarabba, C., and De Gori, P.: Linking the Alps and Apennines subduction systems: new constraints revealed by high-resolution teleseismic tomography, Earth Planet. Sc. Lett., 301, 531-543, https://doi.org/10.1016/j.epsl.2010.11.033, 2011.

Goes, S., Spakman, W., and Bijwaard, H.: A lower mantle source for central European volcanism, Science, 286, 1928-1931, https://doi.org/10.1126/science.286.5446.1928, 1999.

Gripp, A. E. and Gordon, R. G.: Young tracks of hotspots and current plate velocities, Geophys. J. Int., 150, 321-361, https://doi.org/10.1046/j.1365-246X.2002.01627.x, 2002.

Handy, M. R., Schmid, S. M., Bousquet, R., Kissling, E., and Bernoulli, D.: Reconciling plate-tectonic reconstructions of Alpine Tethys with the geological-geophysical record of spreading and subduction in the Alps, Earth-Sci. Rev., 102, 121-158, https://doi.org/10.1016/j.earscirev.2010.06.002, 2010.

Handy, M. R., Ustaszewski, K., and Kissling, E.: Reconstructing the Alps-Carpathians-Dinarides as a key to understanding switches in subduction polarity, slab gaps and surface motion, Int. J. Earth Sci., 104, 1-26, https://doi.org/10.1007/s00531-014-10603,2015 .

Heidbach, O., Rajabi, M., Cui, X., Fuchs, K., Müller, B., Reinecker, J., Reiterg, K., Tingay, M., Wenzel, F., Xie, F., Ziegler, M. O., Zoback, M. L., and Zoback, M.: The World Stress Map database release 2016: crustal stress pattern across scales, Tectonophys., 744, 484-498, https://doi.org/10.1016/j.tecto.2018.07.007, 2018.

Helffrich, G.: Lithospheric deformation inferred from teleseismic shear wave splitting observations in the United Kingdom, J. Geophys. Res., 100, 18195-18204, 1995.

Hetényi, G., Molinari, I., Clinton, J., Bokelmann, G., Bondár, I., Crawford, W. C., Dessa, J.-X., Doubre, C., Friederich, W., Fuchs, F., Giardini, D., Gráczer, Z., Handy, M. R., Herak, M., Jia, Y., Kissling, E., Kopp, H., Korn, M., Margheriti, L., Meier, T., Mucciarelli, M., Paul, A., Pesaresi, D., Piromallo, C., Plenefisch, T., Plomerová, J., Ritter, J., Rümpker, G., Šipka, V., Spallarossa, D., 
Thomas, C., Tilmann, F., Wassermann, J., Weber, M., Wéber, Z., Wesztergom, V., Živčić, M., AlpArray Seismic Network Team, AlpArray OBS Cruise Crew, and AlpArray Working Group: The AlpArray Seismic Network: A large scale European experiment to image the Alpine orogen, Surv. Geophys., 39, 1009-1033, https://doi.org/10.1007/s10712-018-9472-4, 2018.

INGV Seismological Data Centre: Rete Sismica Nazionale (RSN), Istituto Nazionale di Geofisica e Vulcanologia (INGV), Italy, https://doi.org/10.13127/SD/X0FXNH7QFY, 2006.

Istituto Nazionale di Geofisica e Vulcanologia: Seismic Network SI Sudtirol Network, Italy, available at: http://cnt.rm.ingv.it/en/ instruments/network/SI, last access: 1 July 2020.

Jung, H., Katayama, I., Jiang, Z., Hiraga, T., and Karato, S.-I.: Effect of water and stress on the lattice-preferred orientation of olivine, Tectonophys, 421, 1-22, 2006.

Kennett, B. L. N., Engdahl, E. R., and Buland, R.: Constraints on seismic velocities in the earth from traveltimes, Geophys. J. Int., 122, 108-124, 1995.

Király, A., Faccenna, C., and Funiciello, F.: Subduction zones interaction around the Adria microplate and the origin of the Apenninic arc, Tectonics, 37, 3941-3953, https://doi.org/10.1029/2018TC005211, 2018.

Kreemer, C., Blewitt, G., and Klein, E. C.: A geodetic plate motion and Global Strain Rate Model, Geochem. Geophys. Geosyst., 15, 3849-3889, https://doi.org/10.1002/2014GC005407, 2014.

Kummerow, J., Kind, R., and Transalp Working Group: Shear wave splitting in the Eastern Alps observed at the TRANSALP network, Tectonophysics, 414, 117-125, https://doi.org/10.1016/j.tecto.2005.10.023, 2006.

Kuo, B.-Y., Lin, S.-C., and Lin, Y.-W.: SKS splitting and the scale of vertical coherence of the Taiwan mountain belt, J. Geophys. Res., 123, 1366-1380, https://doi.org/10.1002/2017JB014803, 2018.

Levin, V., Long, M. D., Skryzalin, P., Li, Y., and López, I.: Seismic evidence for a recently formed mantle upwelling beneath New England, Geology, 46, 87-90, 2018.

Liddell, M. V., Bastow, I., Darbyshire, F., Gilligan, A., and Pugh, S.: The formation of Laurentia: Evidence from shear wave splitting, Earth Planet Sc. Lett., 479, 170-178, https://doi.org/10.1016/j.epsl.2017.09.030, 2017.

Lippitsch, R., Kissling, E., and Ansorge, J.: Upper mantle structure beneath the Alpine orogen from high-resolution teleseismic tomography, J. Geophys. Res., 108, 2376, https://doi.org/10.1029/2002JB002016, 2003.

Long, M. and Silver, P.: Shear Wave Splitting and Mantle Anisotropy: Measurements, Interpretations, and New Directions, Surv. Geophys., 30, 407-461, https://doi.org/10.1007/s10712009-9075-1, 2009.

Long, M. D. and Becker, T. W.: Mantle dynamics and seismic anisotropy, Earth Planet. Sc. Lett., 297, 341-354, https://doi.org/10.1016/j.epsl.2010.06.036, 2010.

Long, M. D., Ford, H. A., Abrahams, L., and Wirth, E. A.: The seismic signature of lithospheric deformation beneath eastern North America due to Grenville and Appalachian orogenesis, Lithosphere, 9, 987-1001, https://doi.org/10.1130/L660.1, 2017.

Lucente, F. P., Margheriti, L., Piromallo, C., and Barruol, G.: Seismic anisotropy reveals the long route of the slab through the western-central Mediterranean mantle, Earth Planet. Sc. Lett., 241, 517-529, https://doi.org/10.1016/j.epsl.2005.10.041, 2006.
Mainprice, D., Barruol, G., and Ismail, W. B.: The seismic anisotropy of the Earth's mantle: from single crystal to polycrystal, in: Earth's Deep Interior: Mineral physics and tomography from the atomic to the global scale, edited by: Karato, S.I., Forte, A. M., Lieberman, R. C., Masters, G., and Stixrude, L., AGU Geophysical Monograph, 117, 237-264, 2000.

Margheriti, L., Lucente, F. P., and Pondrelli, S.: SKS splitting measurements in the Apenninic-Tyrrhenian domain (Italy) and their relation with lithospheric subduction and mantle convection, J. Geophys. Res., 108, https://doi.org/10.1029/2002JB001793, 2003.

Meissner, R., Mooney, W. D., and Artemieva, I.: Seismic anisotropy and mantle creep in young orogens, Geophys. J. Int., 149, 1-14, https://doi.org/10.1046/j.1365-246X.2002.01628.x, 2002.

Miller, M. S. and Agostinetti, N. P.: Insights into the evolution of the Italian lithospheric structure from $\mathrm{S}$ receiver function analysis, Earth Planet. Sc. Lett., 345, 49-59, 2012.

Mitterbauer, U., Behm, M., Brückl, E., Lippitsch, R., Guterch, A., Keller, G. R., Koslovskaya, E., Rumpfhuber, E.-M., and Sŭmanovac, F.: Shape and origin of the East-Alpine slab constrained by the ALPASS teleseismic model, Tectonophysics, 510, 195-206, https://doi.org/10.1016/j.tecto.2011.07.001, 2011.

Niu, F. and Perez, A. M.: Seismic anisotropy in the lower mantle: A comparison of wave- form splitting of SKS and SKKS, Geophys. Res. Lett., 31, L24612, https://doi.org/10.1029/2004GL021196, 2004.

Petrescu, L., Stuart, G., Houseman, G., and Bastow, I.: Upper mantle deformation signatures of craton-orogen interaction in the Carpathian-Pannonian region from SKS anisotropy analysis, Geophys. J. Int., 220, 2105-2118, https://doi.org/10.1093/gji/ggz573, 2020.

Pearce, J. and Mittleman, D.: Defining the Fresnel zone for broadband radiation, Phys. Rev. E, 66, https://doi.org/10.1103/PhysRevE.66.056602, 2002.

Piromallo, C. and Faccenna, C.: How deep can we find the traces of Alpine subduction?, Geophys. Res. Lett., 31, L06605, https://doi.org/10.1029/2003GL019288, 2004.

Piromallo, C. and Morelli, A.: P wave tomography of the mantle under the Alpine- Mediterranean area, J. Geophys. Res., 108, 2065, https://doi.org/10.1029/2002JB001757, 2003.

Plenefisch, T., Klinge, K., and Kind, R.: Upper mantle anisotropy at the transition zone of the Saxothuringicum and Moldanubicum in southeast Germany revealed by shear wave splitting, Geophys. J. Int., 144, 309-319, https://doi.org/10.1046/j.0956540X.2000.01316.x, 2001.

Plomerová, J. and Babuska, V.: Long memory of mantle lithosphere fabric - European LAB constrained from seismic anisotropy, Lithos, 120, 131-143, 2010.

Qorbani, E., Bianchi, I., and Bokelmann, G.: Slab detachment under the Eastern Alps seen by seismic anisotropy, Earth Planet. Sc. Lett., 409, 96-108, https://doi.org/10.1016/j.epsl.2014.10.049, 2015.

Qorbani, E., Bokelmann, G., Kovács, I., Horváth, F., and Falus, G.: Deformation in the asthenospheric mantle beneath the Carpathian-Pannonian Region, J. Geophys. Res., 121, 66446657, https://doi.org/10.1002/2015JB012604, 2016.

Restivo, A. and Helffrich, G.: Teleseismic shear wave splitting measurements in noisy environments, Geophys. J. Int., 137, 821-830, 1999. 
Restivo, A. and Helffrich, G.: Core-mantle boundary structure investigated using SKS and SKKS polarization anomalies, Geophys. J. Int., 165, 288-302, 2006.

Ribe, N. M.: Seismic anisotropy and mantle flow, J. Geophys. Res., 94, 4213-4223, https://doi.org/10.1029/JB094iB04p04213, 1989.

Ritter, J. R., Jordan, M., Christensen, U. R., and Achauer, U.: A mantle plume below the Eifel volcanic fields, Germany, Earth Planet. Sc. Lett., 186, 7-14, https://doi.org/10.1016/S0012821X(01)00226-6, 2001.

Rosenberg, C. L., Berger, A., Bellahsen, N., and Bousquet, R.: Relating orogen width to shortening, erosion, and exhumation during Alpine collision, Tectonics, 34, 1306-1328, https://doi.org/10.1002/2014TC003736, 2015.

Salimbeni, S., Pondrelli, S., Margheriti, L., Park, J., and Levin, V.: SKS splitting measurements beneath Northern Apennines region: a case of oblique trench-retreat, Tectonophys., 462, 68-82, https://doi.org/10.1016/j.tecto.2007.11.075, 2008.

Salimbeni, S., Pondrelli, S., and Margheriti, L.: Hints on the deformation penetration induced by subductions and collision processes: Seismic anisotropy beneath the Adria region (Central Mediterranean), J. Geophys. Res., 118, 5814-5826, https://doi.org/10.1002/2013JB010253, 2013.

Salimbeni, S., Malusà, M. G., Zhao, L., Guillot, S., Pondrelli, S., Margheriti, L., Paul, A., Solarino, S., Aubert, C., Dumont, T., Schwartz, S., Wang, Q., Xu, X., Zheng, T., and Zhu, R.: Active and fossil mantle flows in the western Alpine region unravelled by seismic anisotropy analysis and highresolution $\mathrm{P}$ wave tomography, Tectonophysics, 731, 35-47, https://doi.org/10.1016/j.tecto.2018.03.002, 2018.

Savage, M.: Seismic anisotropy and mantle deformation: What have we learned from shear wave splitting?, Rev. Geophys., 37, 65106, https://doi.org/10.1029/98RG02075, 1999.

Schmid, S., Aebli, H., Heller, F., and Zingg, A.: The role of the Periadriatic Line in the tectonic evolution of the Alps, in: Alpine Tectonics, edited by: Coward, M. P., Dietrich, D., and Park, R. G., Geological Society, London, Special Publications, 45, 153$171,1989$.

Schmid, S. M., Fügenschuh, B., Kissling, E., and Schuster, R.: Tectonic map and overall architecture of the Alpine orogen, Eclogae Geol. Helv., 97, 93-117, https://doi.org/10.1007/s00015004-1113-x, 2004.

Schmid, S. M., Bernoulli, D., Fügenschuh, B., Matenco, L., Schefer, S., Schuster, R., Tischler, M., and Ustaszewski, K.: The Alpine-Carpathian-Dinaridic orogenic system: correlation and evolution of tectonic units, Swiss J. Geosci., 101, 139-183, https://doi.org/10.1007/s00015-008-1247-3, 2008.

Schumacher, M. E.: Upper Rhine Graben: role of preexisting structures during rift evolution, Tectonics, 21, 6-1-6-17, 2002.

Silver, P. and Chan, G.: Shear wave splitting and subcontinental mantle deformation, J. Geophys. Res., 96, 16429-16454, https://doi.org/10.1029/91JB00899, 1991.

Silver, P. and Chan, W.: Implications for continental structure and evolution from seismic anisotropy, Nature, 335, 34-39, 1988.

Silver, P. G.: Seismic anisotropy beneath the continents: Probing the depths of geology, Annu. Rev. Earth Planet. Sc., 24, 385-432, 1996.
Sinclair, H. D.: Tectonostratigraphic model for underfilled peripheral foreland basin: An Alpine perspective, Geol. Soc. Am. Bull., 109, 324-346, 1997.

Song, T.-R. A. and Kawakatsu, H.: Subduction of oceanic asthenopshere: evidence from sub-slab seismic anisotropy, Geophys. Res. Lett., 39, L17301, https://doi.org/10.1029/2012GL052639, 2012.

Swiss Seismological Service (SED) at ETH Zurich: National Seismic Networks of Switzerland; ETH Zürich, Other/Seismic Network, https://doi.org/10.12686/sed/networks/ch, 1983.

Tommasi, A., Godard, M., Coromina, G., Dautria, J., and Barsczus, H.: Seismic anisotropy and compositionally induced velocity anomalies in the lithosphere above mantle plumes: a petrological and microstructural study of mantle xenoliths from French Polynesia, Earth Planet. Sc. Lett., 227, 539-556, https://doi.org/10.1016/j.epsl.2004.09.019, 2004.

Ustaszewski, K., Schmid, S., Fügenschuh, B., Tischler, M., Kissling, E., and Spakman, W.: A map-view restoration of the Alpine-Carpathian-Dinaridic system for the Early Miocene, Swiss J. Geosci., 101, 273-294, 2008.

Walther, M., Plenefisch, T., and Rümpker, G.: Automated analysis of SKS splitting to infer upper mantle anisotropy beneath Germany using more than $20 \mathrm{yr}$ of GRSN and GRF data, Geophys. J. Int., 196, 1207-1236, https://doi.org/10.1093/gji/ggt456, 2013.

Venereau, C. M. A., Martin-Short, R., Bastow, I. D., Allen, R. M., and Kounoudis, R.: The role of variable slab dip in driving mantle flow at the eastern edge of the Alaskan subduction margin: Insights from shear-wave splitting, Geochem. Geophy. Geosy., 20, 2433-2448, https://doi.org/10.1029/2018GC008170, 2019.

Wang, C.-Y., Flesch, L. M., Silver, P. G., Chang, L.-J., and Chan, W. W.: Evidence for mechanically coupled lithosphere in central Asia and resulting implications, Geology, 36, 363-366, https://doi.org/10.1130/G24450A.1, 2008.

Wessel, P. and Smith, H. F.: New, improved version of the generic mapping tools released, Eos T. Am. Geophys. Un., 539, 579-579, https://doi.org/10.1029/98EO00426, 1998.

Wüstefeld, A. and Bokelmann, G.: Null detection in shear-wave splitting measurements, Bull. Seismol. Soc. Am., 97, 1204, https://doi.org/10.1785/0120060190, 2007.

Wüstefeld, A., Al-Harrasi, O., Verdon, J., Wookey, J., and Kendall, J.-M.: A strategy for automated analysis of passive microseismic data to image seismic anisotropy and fracture characteristics, Geophys. Prospect., 58, 755-773, https://doi.org/10.1111/j.1365-2478.2010.00891.x, 2010.

Xue, M. and Allen, R. M.: Asthenospheric channeling of the Icelandic upwelling: Evidence from seismic anisotropy, Earth Planet. Sc. Lett., 235, 167-182, https://doi.org/10.1016/j.epsl.2005.03.017, 2005.

Zhao, L., Paul, A., Malusà, M. G., Xu, X., Zheng, T., Solarino, S., Guillot, S., Schwartz, S., Dumont, T., Salimbeni, S., Aubert, C., Pondrelli, S., Wang, Q., and Zhu, R.: Continuity of the Alpine slab unraveled by high-resolution P wave tomography, J. Geophys. Res., 121, 8720-8737, https://doi.org/10.1002/2016JB013310, 2016.

Zhu, H., Bozdağ, E., and Tromp, J.: Seismic structure of the European upper mantle based on adjoint tomography, Geophys. J. Int., 201, 18-52, https://doi.org/10.1093/gji/ggu492, 2015.

Ziegler, P. A.: European Cenozoic rift system, Tectonophys., 208, 91-111, https://doi.org/10.1016/0040-1951(92)90338-7, 1992. 